\title{
Cholesterol-Binding Peptides and Phagocytosis
}

\author{
Antonina Dunina-Barkovskaya \\ Belozersky Institute of Physico-Chemical Biology \\ at Moscow Lomonosov State University \\ Russia
}

\section{Introduction}

Phagocytosis is an important cellular process that in multicellular organisms ensures a defence against microbial invasion and removal of effete/apoptotic cells. Phenomenologically, phagocytosis is a process of internalization or engulfment by a cell of particles of a certain size (more than $0.5 \mu \mathrm{m}$ ) (Ofek et al., 1995; Pratten \& Lloyd, 1986; Koval et al., 1998; Aderem \& Underhill, 1999; Morrissette et al., 1999; Tjelle et al., 2000; May \& Machesky, 2001; Djaldetti et al., 2002). After the contact of a particle with a phagocytozing cell, named "phagocyte" in the 19th century (see Heifets, 1982; Gordon, 2008), plasma membrane underneath the particle forms either invagination or extensions (pseudopods) surrounding the particle and eventually forms a vesicle (phagosome) that delivers the particle inside the cell.

The ability to phagocytoze is an integral feature of eucariotic cells, starting from singlecelled animals to the higher vertebrates. In mammals, most of differentiated cells are able to phagocytoze to a certain extent; specialized cells named "professional phagocytes" (Rabinovitch, 1995) (monocytes, macrophages, neutrophils) do this most efficiently, but the activity of "non-professional" phagocytes is also very important both for anti-microbial defence and for tissue development, remodeling, and repair. For instance, macrophagemediated phagocytosis plays a significant role in muscle tissue regeneration (Tidball \& Wehling-Henricks, 2007). Senescent erythrocytes, mostly removed from circulation by macrophages, are also phagocytozed by epithelial cells of thyroid gland and urinary bladder (Aderem \& Underhill, 1999). Fibroblasts incorporate solid particles - fragments of bone or prosthetic materials (Grinnell, 1984; Knowles et al., 1991). Lung epithelium cells can take up foreign particles inhaled with air (Kato et al., 2003; Saxena et al., 2008). Cells of retinal pigmented epithelium (RPE) phagocytoze and digest the shed outer segment membranes of rods (Rabinovitch, 1995; Aderem \& Underhill, 1999; Krigel et al, 2010), and so on.

The vast diversity of the tasks and performances of the phagocytes may account for the fact that impairments in the phagocytic machinery accompany a number of serious illnesses, such as immunodeficiency (review of Lekstrom-Himes \& Gallin, 2000), rheumatoid arthritis (Turner et al., 1973), retinal dystrophies (Gal et al., 2000), paroxysmal arrhythmia (James, 1994), cystic fibrosis and bronchiectasis (Vandivier et al., 2002). Macrophages are shown to be involved in promoting tumor angiogenesis, an essential step in the tumor progression to 
malignancy (Lin et al., 2006). Defective phagocytic clearance of apoptotic cells and macrophages as such are involved in the development of the aterosclerotic lesions that initiate acute thrombotic and vascular diseases, including myocardial infarction and stroke (Lucas \& Greaves, 2001; Takahashi et al., 2002). Therefore, understanding the molecular mechanisms of phagocytosis is very important and should help to solve a number of medicinal problems and elaborate new approaches for regulation and control/correction of the phagocytic process.

By now, it is accepted that mechanism of phagocytosis implicates such processes as exocytosis, endocytosis, and adhesion (Aderem \& Underhill, 1999; Botelho et al., 2000; Booth et al., 2001; Dunina-Barkovskaya, 2004; Lee at al., 2007; Fairn et al., 2010). A detailed list of the molecular participants that accomplish the initial membrane reorganization after the contact with the particle, subsequent formation and pinching-off of the phagosomal vesicle, and the components involved in the phagolysosome maturation and recycling has been created (Araki et al., 1996; Hackam et al., 1998; Morrissette et al., 1999; Garin et al., 2001; May \& Machesky, 2001; Booth et al., 2001; Grinstein, 2010). This list includes receptors, membrane lipids, enzymes, cytoskeletal elements, ion-transporting systems (channels, exchanges, and pumps), and accessory cytoplasmic proteins required for membrane fusion, vesicle fission, and oxidative burst. However, molecular mechanism-based tuning of the phagocytic process in vivo and in vitro remains a challenge for the contemporary life sciences. This mini-review will briefly outline the role of cholesterol in the phagocytic process and consider cholesterol-binding peptides as potential tools for modulations and studies of the phagocytic process.

\section{Cholestrol-dependence of the early stages of phagocytosis: What is cholesterol-dependent?}

It has long been shown that the phagocytic process is cholesterol-dependent (Werb \& Cohn, 1972) and very sensitive to sterols (Schreiber et al., 1975). Werb \& Cohn, 1972, in their studies of the membrane composition changes following phagocytosis of latex particles showed that the ability to phagocytoze is regained several hours after the particle engulfment provided that the recovery medium contains cholesterol. Depleting plasma membrane cholesterol considerably inhibits phagocytosis (Peyron et al., 2000; Gatfield \& Pieters, 2000). These observations raise a question: what molecular components accomplishing the phagocytic process are cholesterol-dependent?

\subsection{Examples of cholesterol-dependence of phagocytic receptors}

It is generally agreed that phagocytosis is triggered as a result of binding of cell membrane "phagocytic" receptors with their ligands on the particle surface. Ligand-receptor binding is followed by lateral clustering of the ligand-receptor complexes and by an unexplained way initiates a biochemical cascade leading to the actin polymerization at the sites of the vesicle formation. It is also assumed that the type of ligand (and the receptor involved) determines the "scenario" of the phagocytic process (Aderem \& Underhill, 1999; Tjelle et al., 2000; Greenberg, 2001).

There are many reviews cataloging various types of phagocytic receptors and corresponding signaling cascades leading to the phagosome formation and detachment (Mosser, 1994; 
Greenberg, 1995; Ofek et al., 1995; Aderem \& Underhill, 1999; Astarie-Dequeker et al., 1999; Greenberg, 1999; Peyron, 2000; Tjelle et al., 2000; Greenberg, 2001; Djaldetti et al., 2002). In human phagocytes, the best studied are the receptors recognizing host serum immunoglobulin $\mathrm{G}$ (IgG) and complement $\mathrm{C} 3$ components (C3b and $\mathrm{iC} 3 \mathrm{~b})$. These immune humoral factors are termed opsonins, and particles covered with opsonins are termed opsonized. Phagocytic receptor recognizing Fc-domain of IgG is termed Fc $\gamma R$, and that recognizing $\mathrm{C} 3 \mathrm{~b}$ and $\mathrm{iC} 3 \mathrm{~b}$, complement 3 receptor, or $\mathrm{CR} 3$. In real life, however, phagocytes have to deal with non-opsonized particles, for example, in open wounds or in organs directly contacting with the environment (respiratory tract, gastro-intestinal tract) (Mosser, 1994; Ofek, 1995; Peyron, 2000; Djaldetti et al., 2002). In these cases an important role belongs to various receptors, such as mannose or beta-glucan receptors that bind integral components of the microorganism surface. To this group belong several receptors of macrophages, and in particular CD14, a receptor recognizing bacterial surface components, including lipopolysacharide (LPS); scavenger receptor A, as well as receptors CD36 and CD68 (macrosialin) that participate in phagocytosis of apoptotic cells. There is also phosphatidylserine receptor (PSR) recognizing phosphadidylserine that relocates from the inner to the outer monolayer of the plasma membrane of apoptotic cells (Fadok et al., 1992; Pradhan, 1997; Devitt et al., 1998; Giles et al., 2000; Li et al., 2003).

Although phagocytic receptors (as receptors in general, by definition) are considered "specialized", they are multispecific and multifunctional (Aderem \& Underhill, 1999). This means that they recognize different ligands or certain molecular configurations ("pattern receptors") and can mediate other processes, such as endocytosis or adhesion. A striking example is CD36, multiligand scavenger receptor of class B. These ligands include thrombospondin-1, long-chain fatty acids, modified LDL, retinal photoreceptor outer segments, Plasmodium falciparum malaria-parasitized erythrocytes, sickle erythrocytes, anionic phospholipids, apoptotic cells, and collagens I and IV (Febbraio et al., 2001 and refs. therein). Another example is a complement receptor CR3 - also known as CD11b/CD18 and $\mathrm{a}_{\mathrm{M}} \beta_{2}, \beta_{2}$-integrin - that functions not only as a membrane receptor recognizing iC $3 b$ but also as an adhesion molecule and binds diverse ligands, for example, intercellular adhesion molecule-1 (ICAM-1) (Ross \& Vĕtvicka, 1993; Ofek et al, 1995). Even Fcy receptors may trigger either endocytosis or phagocytosis, depending on the size of the ligand-receptor cluster (Koval et al., 1998; Huang, 2006).

There are a number of works indicating that phagocytic processes involving certain phagocytic receptors are cholesterol-dependent. For example, Han et al., 1997 and Han et al., 1999 showed that lipoprotein lipids and cholesterol can upregulate the expression of the CD36 gene and protein. Moreover, according to Febbraio et al., 2001, CD36 colocalizes with caveolin-1 in specialized cholesterol- and sphingolipid-enriched microdomains of plasma membrane termed rafts. There are plenty of comprehensive reviews considering molecular structure, biophysics, and the roles of rafts in cell physiology (Simons \& Ikonen, 1997; Brown \& London, 2000; Pike, 2003; Lingwood \& Simons, 2010, and references therein). In brief, rafts are defined as protein-lipid domains enriched with cholesterol and sphingomyelin. Rafts feature resistance to non-polar detergents (like Triton X-100), which points to strong interactions between molecules in a raft. At the same time, rafts are dynamic structures: they move laterally in the plane of the membrane, and big rafts can split into smaller ones, which in turn can fuse with each other. In artificial systems, in the absence 
of protein, rafts can be of micron size, while in cell membrane, raft size was reported to be several tens on nanometers. Cholesterol-sequestering agents (e.g., nystatin, filipin, $\beta$ cyclodextrin, etc.) or those interfering with its synthesis and metabolism (e.g., progesterone) prevent raft formation and inhibit cell processes in which rafts are involved, such as caveolar endocytosis. It is proposed that rafts may serve to concentrate signaling molecules and facilitate the integration of signaling cascades.

Another example of cholesterol- (and raft-) dependence concerns CR3-mediated phagocytosis. According to Peyron et al., 2000, nystatin and other cholesterol-sequestering agents (filipin, methyl- $\beta$-cyclodextrin) notably inhibit CR3-mediated phagocytosis of nonopsonized bacteria Mycobacterium kansasii by neutrophils. Moreover, phagocytosis is blocked if glycosylphosphatidylinositol- (GPI-) anchored proteins are removed with phosphatidyl inositol phospholipase C. The authors suggested that CR3-mediated phagocytosis of Mycobacterium kansasii requires binding of CR3 with GPI-ancored proteins localized in rafts. Once CR3 is not associated with rafts, it can mediate phagocytosis of zymozan or opsonized zymozan but not Mycobacterium kansasii. The observations suggest that the phagocytic "scenario" involving a given receptor, CR3, depends on the presence of cholesterol and interaction of the receptor with the lipid.

Fc $\gamma$-receptor-mediated phagocytosis is also cholesterol-dependent. Clustering of Fc $\gamma$ receptors induced by binding to multiple opsonic ligands on a particle leads to phosphorylation of the Fc $\gamma$-immunoreceptor tyrosine-based activation motif (ITAM) by members of the Src family of kinases and followed by recruitment of the kinase Syk. Syk activation in turn initiates a signaling cascade, including activation of phosphatidylinositol 3-kinase (PI 3-kinase) and of the small GTPases Rac and Cdc42, which coordinate actin remodeling (Henry et al., 2004). As was reported (Kwiatkowska \& Sobota, 2001; Katsumata et al., 2001; Kono et al., 2002; Kwiatkowska et al., 2003), one of the earliest signal events after the cross-binding of $\mathrm{Fc} \gamma$ receptors is lateral raft assembly that occurs before the activation of kinases of the Src family and independent of their activity. To trigger the lateral assembly of rafts, sufficient was the expression of ligand-binding monomer Fc $\gamma R$, without signal subunits carrying the activating fragment with tyrosine. Moreover, expression of the ligandbinding fragment of the receptor triggered fast mobilization of calcium. The authors (Kono et al., 2002; Kwiatkowska et al., 2003) suggested that lateral assembly of rafts is caused by ligand-binding subunits of the Fc $\gamma$-receptor and that it is the raft coalescence that triggers the signaling cascade of the biochemical reactions leading to rearrangements of membrane and cytoskeleton and eventually, to the formation of a membrane vesicle containing the particle. The importance of the integrity of the plasma membrane detergent-resistant microdomains for IgG-dependent phagocytosis was also shown by Marois et al., 2011. The authors also reported that phagocytosis of IgG-opsonized zymosan by human neutrophils required an extracellular influx of calcium that was blocked only by antibodies against FcyRIIIb. These data revive the question wheather Fc $\gamma R$ may function as ligand-dependent channels (Young et al., 1983; Young et al., 1985). A quick local change of the ion channel activity at the site of the contact of the phagocyte with a particle remains a possible (but yet unexplored) step in the phagocytic signal cascade. In our hands, phagocytosis of nonopsonized beads by IC-21 macrophages is sensitive to methyl- $\beta$-cyclodextrin and carbenoxolon - glucocorticoid and a connexin channel blocker (Golovkina et al., 2009; Vishniakova et al., 2011). 
Thus, even a brief overview of the very early stages of the phagocytic process shows that at least some of phagocytic receptors depend on cholesterol.

\subsection{Phosphoinositides and lipid rafts in phagocytosis}

It is recognized that successful phagosome formation requires local actin polymerization/depolymerization (Aderem \& Underhill, 1999; Tjelle et al., 2000; May \& Machesky, 2001; Greenberg, 2001; Lee at al., 2007) that dependes on the phosphatidylinsiotol metabolism. A detailed quantitative assessment of membrane remodeling during Fc $\gamma \mathrm{R}$ mediated phagocytosis revealed marked changes in membrane composition that concerned the localization and metabolism of phosphoinositides (Botelho et al., 2000; Lee at al., 2007; Fairn et al., 2010). It was found in particular that at the onset of phagocytosis phosphatidylinositol (PI) 4,5-bisphosphate (PI4,5 $\mathrm{P}_{2}$ ) accumulates at sites where pseudopods are formed. Following the closure and fission of the phagosome, the phosphoinositide concentration drops, while phospholipase $\mathrm{C}_{\gamma}(\mathrm{PLC} \gamma)$ is mobilized and local concentration of DAG increases. The authors suggested that this localized increase in PI4,5 $\mathrm{P}_{2}$ serves as a platform for the robust actin polymerization required for pseudopod extension. Recent works (Fairn et al., 2010; Grinstein, 2010) demonstrated in detail a highly localized sequence of changes in the level of several phosphoinositides as well as phosphatidylserine. The net changes in the content of these anionic phospholipids notably altered the surface charge of the membrane and caused the relocation of membrane-associated proteins due to electrostatic interactions. The authors hypothesize that modification of the membrane surface charge may play a role of an "electrostatic switch" that attracts or repulses proteins carrying polycationic or polyanionic motifs. Perhaps this hypothesis can be further extended: the role of such electrostatic switch may play a charged particle that touches the cell and triggers the phagocytic process.

Are there any correlations beween changes in the phosphoinisitide content and lipid raft assembly during phagocytosis? Lee at al., 2007 reported that there was an obvious clearance of the raft marker YFP-GPI from the base of forming phagosomes within minutes of particle contact and that this clearance resulted from the focal insertion of unlabeled endomembranes that are delivered focally by directed exocytosis. The authors interpreted these results as evidence against the raft involvement in the phagocytic process. However, these findings do not exclude the possibility that the raft formation preceded the observed changes in the phosphatidylinositide contents and possibly triggered these changes. The insertion of the new membranes should displace laterally and/or dilute the molecules and molecular ensembles (and rafts in particular) that initiated the phagocytic signaling cascade.

A number of works suggest close relations between rafts and phosphoinositides. For example, Hope \& Pike, 1996 showed that polyphosphoinositide phosphatase, but not several other phosphoinositide-utilizing enzymes, is highly enriched in a low-density Triton-insoluble membrane fraction that contains caveolin; this fraction is also enriched in polyphosphoinositides, containing approximately one-fifth of the total cellular phosphatidylinositol $(4,5) \mathrm{P}_{2}$. Defacque et al, 2002 suggested that $\mathrm{PI}(4,5) \mathrm{P}_{2}$ may exist in raftlike microdomains on latex bead phagosomes after isolation. On activation of cells with agonists or addition of ATP to the in vitro actin assay, PIPs are rapidly synthesized and may aggregate laterally into larger raft domains. The authors speculate that rafts may provide a 
platform for the proteins and lipids necessary for actin assembly to occur locally on the membrane of latex bead phagosomes.

Thus, the importance of phosphoinositides does not exclude the involvement of rafts in the phagocytosis mechanisms; in contrast, the dynamic functions of these lipid components of the plasma membrane appear to be highly coordinated in time and space throughout the course of the phagocytic process.

\section{Cholesterol-binding sites in integral proteins involved in phagocytosis}

Once phagocytosis is cholesterol-dependent and at least some of the phagocytic receptors aggregate in lipid rafts, it is important to know what structure(s) in these integral proteins makes them cholesterol-sensitive. Epand, 2006 reviewed the structural features of a protein that favour its association with cholesterol-rich domains. One of the best documented of these is certain types of lipidations; relatively new are the sterol-sensing domain (SSD) and the cholesterol recognition/interaction amino acid consensus (CRAC) domain. The latter was first described by $\mathrm{Li} \&$ Papadopolous, 1998 for the peripheral-type benzodiazepine receptor (PBR). The CRAC sequence was formulated as $-\mathrm{L} / \mathrm{V}-(\mathrm{X})_{1-5}-\mathrm{Y}-(\mathrm{X})_{1-5}-\mathrm{R} / \mathrm{K}-$; the presence of this site in C-terminus of PBR was necessary and sufficient for the cholesterol transport (Li \& Papadopolous, 1998; Li et al., 2001). Moreover, the authors found a similar sequence in some other proteins known to interact with cholesterol (apolipoprotein A-I, some enzymes of steroid metabolism (e.g., P450scc (side-chain cleavage P450)), annexin, and some other proteins. Among them was caveolin - an integral protein accompanying caveolae, i.e., domains of plasma membrane containing lipid rafts and participating in caveolin-dependent endocytosis (Pelkmans et al., 2002).

A search for CRAC-like domains in the transmembrane areas of some integral proteins related to phagocytosis was performed by Cheshev et al., 2006. Apart from phagocytic receptor Fc $\gamma R$, the list of the molecules tested included proteins presumably involved in the regulation of the ionic composition in perimembrane cytoplasm during phagocytosis. Activation of phagocytes is accompanied by changes in the activity of the potassium channels of the IRK family (Eder, 1998; Arkett \& Dixon, 1992; DeCoursey \& Cherny, 1996; Colden-Stanfield, 2002). Ionotropic purinoreceptors P2X7 are found in monocytes/macrophages (North, 2002; Gudipatyet al., 2001); they cluster (Connon et al., 2003) and segregate in rafts (Torres et al., 1999). Gap-junction proteins are also known to accumulate in cholesterol-rich rafts (Schubert et al., 2002; Lin et al., 2003; Lin et al., 2004; Dunina-Barkovskaya, 2005). Connexin Cx43 is found in macrophages (Beyer \& Steinberg, 1991; Beyer \& Steinberg, 1993; Anand et al., 2008); colocalization of purinoreceptors P2X7 with connexin Cx43 in macrophages was reported (Beyer \& Steinberg, 1991; Beyer \& Steinberg, 1993; Fortes et al., 2004).

Figure 1 shows the fragments of the proteins aligned versus the CRAC sequence. Most of the proteins studied contained a conservative sequence of hydrophobic amino acids Val, Leu, Tyr, and Trp. This sequence can be described as follows: $(\mathrm{L} / \mathrm{V})_{1-2}-(\mathrm{X})_{1-4}-\mathrm{Y} / \mathrm{F}-(\mathrm{X})_{1-3}-\mathrm{W}$, which is close to the CRAC consensus $\left(\mathrm{L} / \mathrm{V}-(\mathrm{X})_{1-5}-\mathrm{Y}-(\mathrm{X})_{1-5}-\mathrm{R} / \mathrm{K}\right)$. In contrast to PBR that has cholesterol-binding consensus in a cytoplasmic C-terminus, in the integral proteins (Fig. 1) the consensus sequence was always localized in the transmembrane domain. It may account for a slight difference between the PBR cholesterol-binding consensus and the sequences found. 


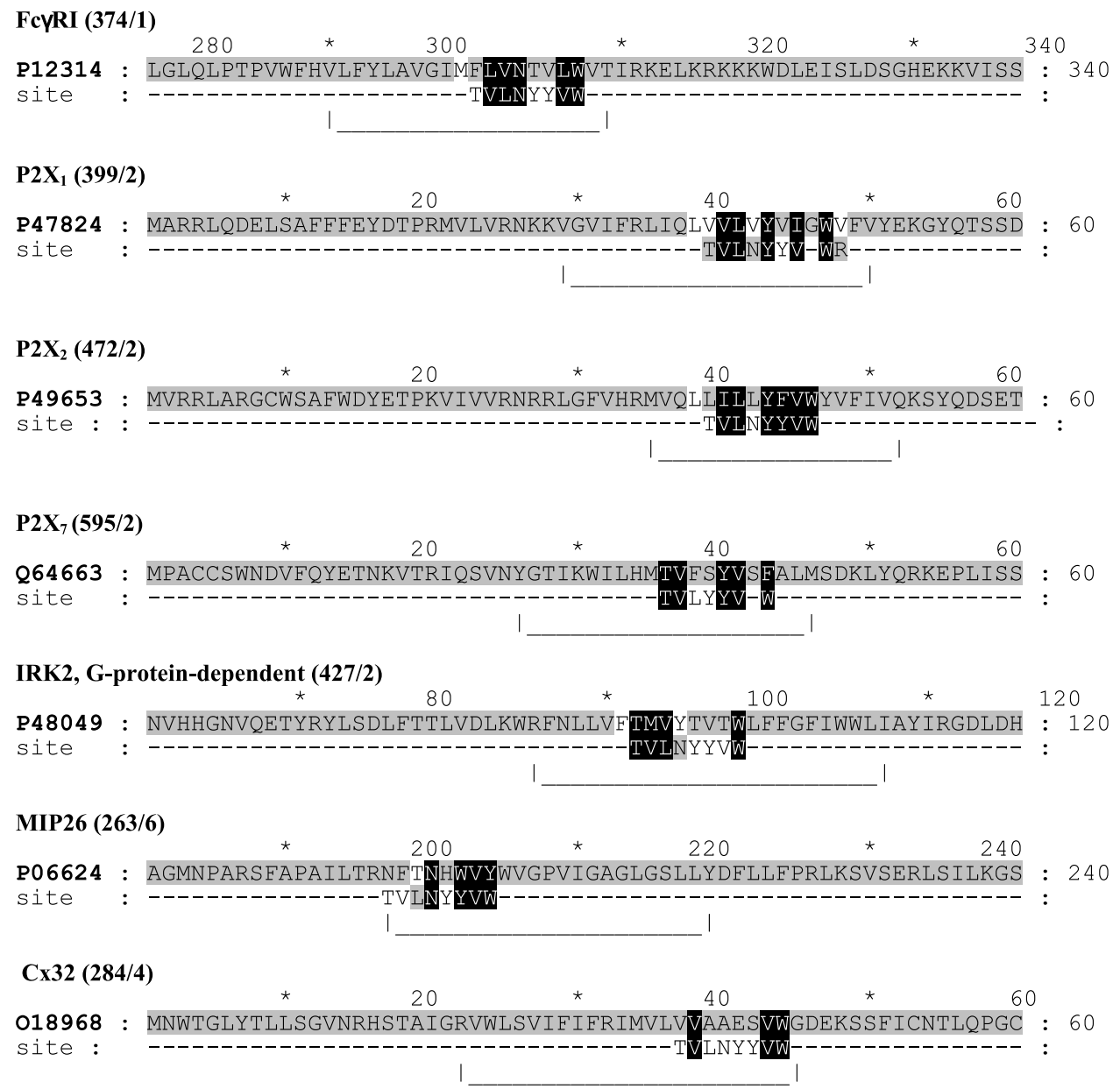

Cx43 (382/4)

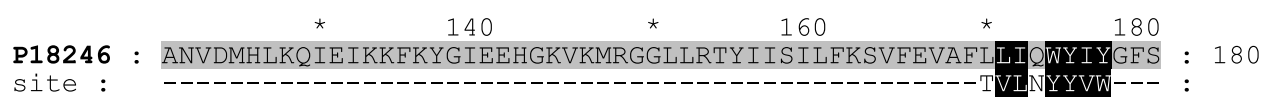

Fig. 1. Proposed cholesterol-binding sites in transmembrane domains of some proteins. Fragments of the proteins studied are highlighted with grey colour; a number at the left is the protein Uniport code (AC); numbers (and asterisks) above the fragments show the aminoacid residue numbers. Cholesterol-binding consensus (TVLNYYVW) is shown below the protein fragment (in the line marked "site"). Shown are the protein fragments ( 60 aminoacid residues), in which the amino-acid sequence was comparable with the cholesterolbinding consensus. Identical or similar amino-acid residues are marked black. A square bracket below shows the position of transmembrane domains. 
The presence in a transmembrane domain of the cholesterol-binding site that is potentially able to intract with cholesterol indicates that at least such interaction is possible. Binding of cholesterol at the level of the transmembrane domain of the receptor may not only account for segregation of the receptors in the lipid rafts at the early stages of phagocytosis (Kono et al., 2002; Kwiatkowska et al., 2003) but also favour an optimal Fc $\gamma \mathrm{R}$ configuration required for further interactions with kinases. As regards the channel proteins, binding of cholesterol may regulate the state of the ion-conducting pore. The channel molecules studied may be involved in the phagocytic process and their cholesterol-dependence may contribute to the cholesterol-dependence of the phagocytic process.

The presence of cholesterol-binding sequence in a number of integral proteins not only explains cholesterol-dependence of their functions. It seems very likely that experimental expression (and overexpression in particular) of integral proteins possessing cholesterolbinding sites may produce a cholesterol-sequestering effect in the transformed cells, similar to the effect of such cholesterol-sequestering agent as nystatin, methyl- $\beta$-cyclodextrin, etc. (Cheshev et al., 2006).

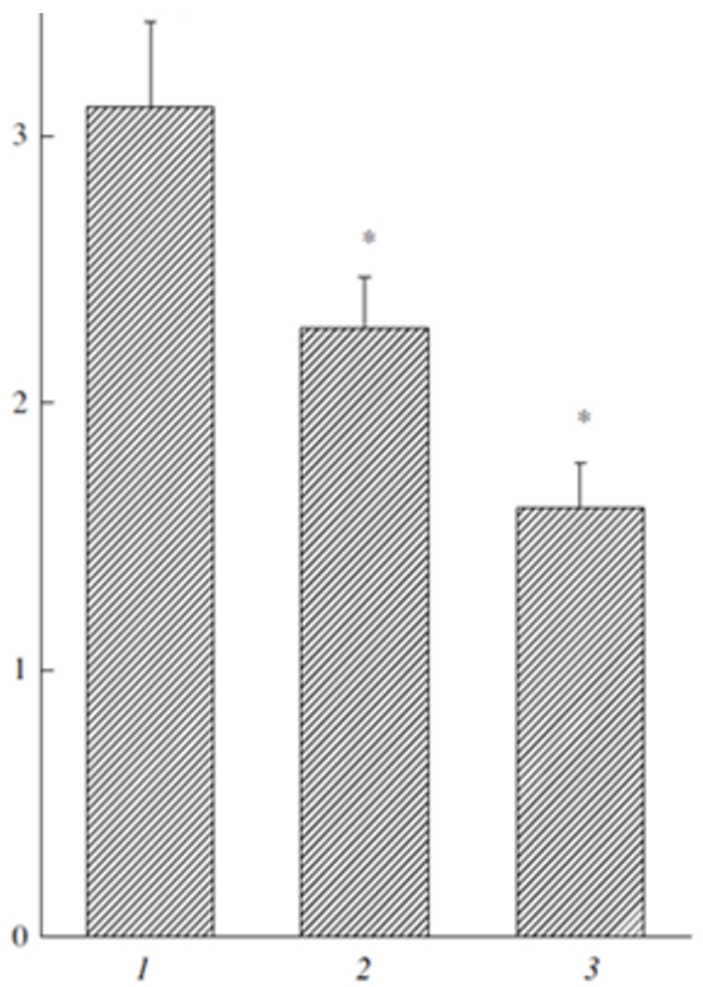

Fig. 2. Effect of cholesterol-binding peptide VLNYYVW on phagocytic activity of IC-21 macrophages (Dunina-Barkovskaya et al., 2007). Results of typical experiment are shown. 1, Control; 2, 1\% DMSO; 3, VLNYYVW (100 $\mu \mathrm{g} / \mathrm{ml})$ in DMSO (1\%). Ordinate, mean number of beads per cell. ${ }^{*}, p<0.05$ vs. control. 
The effect of a cholesterol-binding peptide VLNYYVW corresponding to the consensus cholesterol-binding sequence (Fig.1) on phagocytic activity was tested on IC-21 macrophages (Dunina-Barkovskaya et al., 2007). Phagocytosis was assessed by fluorescent microscopy, using 2- $\mu \mathrm{m}$ non-opsonized fluorescent latex beads. The peptide wase dissolved in DMSO, which turned to affect phagocytic activity by itself: in the presence of $0.5-1.3 \%$ DMSO the number of beads per cell was lower by $20-30 \%$ than in the absence of DMSO. Peptide VLNYYVW (5-100 $\mu \mathrm{g} / \mathrm{ml})$ augmented the inhibitory action of DMSO (Fig. 2). This result suggests that cholesterol-binding peptide may indeed affect the phagocytic process. What is the mechanism of this effect remains to be determined. Peptides may interfere with the interactions between integral proteins and membrane cholesterol and thus hinder the segregation of the proteins in cholesterol-rich domains. Another possibility is a cholesterolsequestering effect similar to that exerted by nystatin, methyl- $\beta$-cyclodextrin and analogous substances. The formation of non-functional rafts in the membranes, like what was observed in artificial systems by Epand et al., 2003 is also possible. The authors showed that peptide LWYIK, a fragment of cholesterol-binding sequence, induced raft formation in phosphatidylcholine-cholesterol bilayer membranes.

\section{Conclusion}

Phagocytosis is an important cellular process underlying the innate and acquired immunity and involved in tissue remodelling throughout development or repair. Phagocytosis is a multi-stage process that engages endocytosis, exocytosis, and adhesion mechanisms. Highly coordinated local and dynamic rearrangements of the membrane underneath the target particle result in its engulfment and intracellular processing. Phagocytosis is a cholesteroldependent process. One of the reason of this cholesterol dependency is the formation of cholesterol-enriched domains in plasma membrane, where phagocytic receptors ( $F c \gamma R$, in particular) may cluster and form supramolecular complexes required to set off and perform a further cascade of biochemical reactions leading to the rearrangements of cytoskeleton and formation of a membrane vesicle containing the particle. A molecular basis for direct interaction between integral proteins and membrane cholesterol can be provided by a cholesterol recognition/interaction amino acid consensus (CRAC) $-\mathrm{L} / \mathrm{V}-(\mathrm{X})_{1-5}-\mathrm{Y}-(\mathrm{X})_{1-5}-\mathrm{R} / \mathrm{K}-$, described for a cholesterol-binding site of the peripheral-type benzodiazepine receptor ( $\mathrm{Li} \&$ Papadopolous, 1998; Li et al., 2001). Alignment of this site with amino acid sequences of a phagocytic receptor FcyRI and some ionic channels that may be involved in the phagocytic process and/or are capable of clustering in rafts (e.g., purinoreceptors and connexins) revealed that most of the proteins studied possessed a relatively conservative hydrophobic amino-acid sequence (Val-Leu---Tyr---Trp) analogous to that in the PBR cholesterol-binding site. This sequence was always localized in a transmembrane domain of a protein (Cheshev et al., 2006). Functional activity of a cholesterol-binding peptide VLNYYVW was tested and confirmed on cultured macrophages IC-21. Cholesterol-binding peptides can thus be a useful tool for further investigations and possibly serve for correction of phagocytosis and other cholesterol-dependent processes.

\section{Acknowledgments}

I appreciate enthusiasm and support of my colleaugues Kh.S. Vishniakova and I.I.Kireev. 


\section{References}

Aderem \& Underhill, 1999 Aderem, A. \& Underhill, D.M. (1999). Mechanisms of Phagocytosis in Macrophages, Ann. Rev. Immunol., vol. 17, pp. 593-623.

Anand R.J., Dai S., Gribar S.C., Richardson W., Kohler J.W., Hoffman R.A., Branca M.F., Li J., Shi X.H., Sodhi C.P., Hackam D.J. (2008). A Role for Connexin43 in Macrophage Phagocytosis and Host Survival after Bacterial Peritoneal Infection, J. Immunol., vol. 181 (12), pp. 8534-8543.

Araki, N., Johnson, M.T. \& Swanson, J.A. (1996). A Role for Phosphoinositide 3-Kinase in the Completion of Macropinocytosis and Phagocytosis by Macrophages, J. Cell Biol., vol. 135, pp. 1249-1260.

Arkett, S.A., Dixon, S.J. \& Sims, S.M. (1992). Substrate Influences Rat Osteoclast Morphology and Expression of Potassium Conductances, J. Physiol., vol. 458, pp. 633-653.

Astarie-Dequeker, C., N'Diaye, E.-N., Le Cabec, V., Rittig, M.G., Prandi, J., MaridonneauParini, I. (1999). Infection and Immunity, vol. 67, pp. 469-477.

Beyer, E.C. \& Steinberg, T.H. (1991). Evidence That the Gap Junction Protein Connexin-43 Is the ATP-Induced Pore of Mouse Macrophages, J. Biol. Chem., vol. 266 (13), pp. 7971-7974.

Beyer, E.C. \& Steinberg, T.H. (1993). Connexins, Gap-Junction Proteins, and ATP-Induced Pores in Macrophages, Progress in Cell Research, vol. 3. Gap Junctions. Ed. Hall J.E., Zampighi G.A., Davis R.M. Amsterdam: Elsevier Sci. Publ., pp. 71-74.

Booth, J.W., Trimble, W.S. \& Grinstein, S. (2001). Membrane Dynamics in Phagocytosis, Seminars Immunol., vol. 13, pp. 357-364.

Botelho, R.J., M. Teruel, R. Dierckman, R. Anderson, A. Wells, J.D. York, T. Meyer, and S. Grinstein. (2000). Localized Biphasic Changes in Phosphatidylinositol-4,5bisphosphate at sites of Phagocytosis, J. Cell Biol., vol. 151, pp. 1353-1368.

Brown, D.A. \& London, E. (2000). Structure and Function of Sphingolipid- and CholesterolRich Membrane Rafts, J. Biol. Chem., vol. 275, pp. 17221-17224.

Cheshev, D.A., Chekanov, N.N. \& Dunina-Barkovskaya, A.Ya. (2006). Cholesterol1Binding Sites in Transmembrane Domains of Integral Membrane Proteins Involved in Phagocytosis and/or Capable of Clustering in Lipid Rafts, Biologicheskie membrany (Rus.), vol. 23 (1), pp. 69-73.

Colden-Stanfield, M. (2002). Clustering of Very Late Antigen-4 Integrins Modulates $\mathrm{K}^{+}$ Currents to Alter $\mathrm{Ca}^{2+-}$-mediated Monocyte Function, Am. J. Physiol. Cell Physiol., vol. 283 (3), pp. C990-C1000.

Connon, C.J., Young, R.D. \& Kidd, E.J. (2003). P2X7 Receptors Are Redistributed on Human Monocytes after Pore Formation in Response to Prolonged Agonist Exposure, Pharmacology, vol. 67 (3), pp. 163-168.

DeCoursey, T.E. \& Cherny, V.V. (1996). Voltage-Activated Proton Currents in Human THP1 Monocytes, J. Membr. Biol., vol. 152, pp. 131-140.

Defacque, H., Bos, E., Garvalov, B., Barret, C., Roy, Ch., Mangeat, P., Shin, Hye-Won, Rybin, V. \& Griffiths, G. (2002). Phosphoinositides Regulate Membrane-dependent Actin Assembly by Latex Bead Phagosomes. Molecular Biology of the Cell, vol. 13, 11901202. 
Devitt, A., Moffatt, O.D., Raykundalia, C., Capra, J.D., Simmons, D.L. \& Gregory, C.D. (1998). Human CD14 Mediates Recognition and Phagocytosis of Apoptotic Cells, Nature, vol. 392, pp. 505-509.

Djaldetti, M., Salman, H., Bergman, M., Djaldetti, R. \& Bessler, H. (2002). Phagocytosis--the Mighty Weapon of the Silent Warriors. Microscopy Research and Technique. vol. 57, pp. 421-431.

Dunina-Barkovskaya, A.Y. (2004). Phagocytosis - Three in One: Endocytosis, Exocytosis, and Adhesion, Biologicheskie membrany (Rus.), vol. 21 (4), pp. 245-272.

Dunina-Barkovskaya, A.Ya. (2005). Are Gap Junctions Protein-Lipid Rafts? Biologicheskie membrany (Rus.), vol. 22 (1), pp. 27-33.

Dunina-Barkovskaya, A.Ya., Vishniakova, Kh.S., Cheshev, D.A., Chekanov, N.N., Bujurina, I.M. (2007). Effects of DMSO and Cholesterol-binding Peptides on Phagocytic Activity of Cultured Macrophages IC-21, Biologicheskie membrany (Rus.), vol. 24 (6), pp. 451-456.

Eder, C. (1998). Ion channels in microglia, J. Cell Biol., vol. 275, pp. C327-C342.

Epand, R.M. (2006). Cholesterol and the Interaction of Proteins with Membrane Domains, Prog Lipid Res., vol. 45 (4), pp. 279-294.

Epand, R.M., Sayer, B.G. \& Epand R.F. (2003). Peptide-induced Formation of Cholesterolrich Domains, Biochemistry, vol. 42 (49), pp. 14677-14689.

Fadok, V.A., Voelker, D.R., Campbell, P.A., Cohen, J.J., Bratton, D.L. \& Henson, P.M. (1992). Exposure of Phosphatidylserine on the Surface of Apoptotic Lymphocytes Triggers Specific Recognition and Removal by Macrophages, J. Immunol., vol. 148, pp. 22072216.

Fairn, G.D., Ogata, K., Botelho, R.J., Stahl, Ph.D., Anderson, R.A., de Camilli, P., Meyer, T., Wodak, Sh. \& Grinstein, S. (2010). An Electrostatic Switch Displaces Phosphatidylinositol Phosphate Kinases from the Membrane during Phagocytosis, J. Cell Biol., vol. 187 (5), pp. 701-714.

Febbraio, M., Hajjar, D.P. \& Silverstein, R.L. (2001). CD36: A Class B Scavenger Receptor Involved in Angiogenesis, Aterosclerosis, Inflammation and Lipid Metabolism, J. Clin. Invest., vol. 108, pp. 785-791.

Fortes, F.S.A., Pecora, I.L., Persechini1, P.M., Hurtado, S., Costa, V., Coutinho,1S.R., Braga, M.B.M., Silva-Filho, F.C., Bisaggio, R.C., de Farias, F.P., Scemes, E., Campos de Carvalho, A.C. \& Goldenberg, R.C.S. (2004). Modulation of Intercellular Communication in Macrophages: Possible Interactions between Gap Junctions and P2 Receptors, J. Cell Sci., vol. 117, pp. 4717-4726.

Fuki, I.V., Meyer, M.E. \& Williams K.J. (2000). Transmembrane and Cytoplasmic Domains of Syndecan Mediate a Multi-step Endocytic Pathway Involving Detergent-insoluble Membrane Rafts, Biochem. J., vol. 351 (3), pp. 607-612.

Gal, A., Li, Y., Thompson, D.A., Weir, J., Orth, U., Jacobson, S.G., Apfelstedt-Sylla, E. \& Vollrath, D. (2000). Mutations in MERTK, the Human Orthologue of the RCS Rat Retinal Dystrophy Gene, Cause Retinitis Pigmentosa, Nat. Genet., vol. 26 (3), pp. 270-271. 
Garin, J., Diez, R., Kieffer, S., Dermine, J.F., Duclos, S., Gagnon, E., Sadoul, R., Rondeau, C. \& Desjardins, M. (2001). The Phagosome Proteome: Insight into Phagosome Functions, J. Cell Biol., vol. 152, pp. 165-180.

Gatfield, J. \& Pieters, J. (2000). Essential Role for Cholesterol in Entry of Mycobacteria into Macrophages, Science, vol. 288 (5471), pp. 1647-1650.

Giles, K.M., Hart, S.P., Haslett, C., Rossi, A.G. \& Dransfield, I. (2000). An Appetite for Apoptotic Cells? Controversies and Challenges, Br. J. Haematol., vol. 109, pp. 1-12.

Golovkina, M.S., Skachkov, I.V., Metelev, M.V., Kuzevanov, A.V., Vishniakova, Kh.S., Kireev, I.I. \& Dunina-Barkovskaya, A.Ya. (2009). Serum-Induced Inhibition of the Phagocytic Activity of Cultured Macrophages IC-21. Biologicheskie membrany (Rus.), vol. 26 (5), pp. 379-386 [Translated version in: Biochemistry (Moscow) Suppl. Series A: Membrane and Cell Biology (2009), vol. 4 (3), pp. 412-419].

Gordon, S. (2008). Elie Metchnikoff: Father of Natural Immunity, Eur. J. Immunol., vol. 38 (12), pp. 3257-3264.

Greenberg, S. (2001). Diversity in Phagocytic Signalling, J. Cell Science, vol. 114, pp. 10391040.

Greenberg, S. (1995). Signal Transduction of Phagocytosis, Trend Cell Biol., vol. 5, pp. 93-99.

Greenberg, S. (1999). Modular Components of Phagocytosis, J. Leukoc. Biol., vol. 66, pp. 712717.

Grinnell, F. (1984). Fibroblast Spreading and Phagocytosis: Similar Cell Responses to Different-sized Substrata, J. Cell Physiol., vol. 119, pp. 58-64.

Grinstein, S. (2010) Imaging Signal Transduction during Phagocytosis: Phospholipids, Surface Charge, and Electrostatic Interactions, Am. J. Physiol. Cell Physiol., vol. 299 (5), C876-C881.

Gudipaty, L., Humphreys, B.D., Buel, G. \& Dubyak, G.R. (2001). Regulation of P2X 7 nucleotide receptor function in human monocytes by extracellular ions and receptor density, Am. J. Physiol. Cell Physiol., vol. 280, pp. C943-C953.

Hackam, D.J., Rotstein, O.D., Sjolin, C., Schreiber, A.D., Trible, W.S. \& Grinstein, S. (1998). vSNARE-Dependent Secretion is Required for Phagocytosis, Proc. Natl. Acad. Sci. USA., vol. 95, pp. 11691-11696.

Han, J., Hajjar, D.P., Febbraio, M. \& Nicholson, A.C. (1997). Native and Modified Low Density Lipoproteins Increase the Functional Expression of the Macrophage Class B Scavenger Receptor, CD36, J. Biol. Chem., vol. 272, pp. 21654-21659.

Han, J., Hajjar, D.P., Tauras, J.M. \& Nicholson, A.C. (1999). Cellular Cholesterol Regulates Expression of the Macrophage Type B Scavenger Receptor, CD36, J. Lipid. Res., vol. 40, pp. 830-838.

Heifets, L. (1982). Centennial of Metchnikoff's Discovery, J.Reticuloendothel. Soc., vol. 31 (5), pp. 381-391.

Henry, R.M., Hoppe, A.D., Joshi, N. \& Swanson, J.A. (2004). The Uniformity of Phagosome Maturation in Macrophages, J. Cell Biol., vol. 164 (2), pp. 185-194.

Hope, H.R. \& Pike, L.J. (1996). Phosphoinositides and Phosphoinositide-utilizing Enzymes in Detergent-insoluble Lipid Domains, Mol. Biol. Cell, vol. 7 (6), pp. 843-851. 
Huang, Z.Y., Barreda, D.R., Worth, R.G., Indik, Z.K., Kim, M.K., Chien, P. \& Schreiber, A.D. (2006). Differential Kinase Requirements in Human and Mouse Fc $\gamma$ Receptor Phagocytosis and Endocytosis, J. Leukoc. Biol., vol. 80 (6), pp. 1553-1562.

James, T.N. (1994). Normal and Abnormal Consequences of Apoptosis in the Human Heart from Postnatal Morphogenesis to Paroxysmal Arrhythmias, Circulation, vol. 90, pp. 556-573.

Kato, T., Yashiro, T., Murata, Y., Herbert, D.C., Oshikawa, K., Bando, M., Ohno, S. \& Sugiyama, Y. (2003). Evidence that Exogenous Substances Can Be Phagocytized by Alveolar Epithelial Cells and Transported into Blood Capillaries, Cell Tissue Res., vol. 311, pp. 47-51.

Katsumata, O., Hara-Yokoyama, M., Sautès-Fridman, C., Nagatsuka, Y., Katada, T., Hirabayashi, Y., Shimizu, K., Fujita-Yoshigaki, J., Sugiya, H. \& Furuyama, S. (2001). Association of Fc $\gamma$ RII with Low-density Detergent-resistant Membranes Is Important for Cross-linking-dependent Initiation of the Tyrosine Phosphorylation Pathway and Superoxide Generation, J. Immunol., vol. 167 (10), pp. 5814-5823.

Knowles, G.C., McKeown, M., Sodek, J. \& McCulloch, C.A. (1991). Mechanism of Collagen Phagocytosis by Human Gingival Fibroblasts: Importance of Collagen Structure in Cell Recognition and Internalization, J. Cell Sci., vol. 98, pp. 551-558.

Kono, H., Suzuki, T., Yamamoto, K., Okada, M., Yamamoto, T. \& Honda, Z. (2002). Spatial Raft Coalescence Represents an Initial Step in FcүR Signaling, J.Immunol., vol. 169, pp. 193-203.

Koval, M., Preiterb, K., Adles, C., Stahl, P.D. \& Steinberg, T.H. (1998). Size of IgG-opsonized Particles Determines Macrophage Response during Iternalization, Exp. Cell Res., vol. 242, pp. 265-273.

Krigel, A., Felder-Schmittbuhl, M.P. \& Hicks, D. (2010). Circadian-Clock Driven Cone-Like Photoreceptor Phagocytosis in the Neural Retina Leucine Zipper Gene Knockout Mouse, Mol. Vis., vol. 16, pp. 2873-2881.

Kwiatkowska, K. \& Sobota, A. (2001). The Clustered Fc $\gamma$ Receptor II Is Recruited to Lyncontaining Membrane Domains and Undergoes Phosphorylation in a Cholesteroldependent Manner, Eur. J. Immunol., vol. 31 (4), pp. 989-998.

Kwiatkowska, K., Frey, J. \& Sobota A. (2003). Phosphorylation of FcүRIIA Is Required for the Receptor-induced Actin Rearrangement and Capping: The Role of Membrane Rafts, J. Cell Sci., vol. 116 (Pt 3), pp. 537-550.

Lee, W.L., Mason, D., Schreiber, A.D. \& Grinstein S. (2007). Quantitative Analysis of Membrane Remodeling at the Phagocytic Cup. Molecular Biology of the Cell. Vol. 18, 2883-2892

Lekstrom-Himes, J.A. \& Gallin, J.I. (2000). Immunodeficiency Diseases Caused by Defects in Phagocytes, N. Engl. J. Med., vol. 343 (23), pp. 1703-1714.

Li, H. \& Papadopoulos, V. (1998). Peripheral-type Benzodiazepine Receptor Function in Cholesterol Transport. Identification of a Putative Cholesterol Recognition/Interaction Amino Acid Sequence and Consensus Pattern, Endocrinology, vol. 139 (12), pp. 4991-4997.

Li, H., Yao, Z., Degenhardt, B., Teper, G. \& Papadopoulos, V. (2001). Cholesterol Binding at the Cholesterol Recognition/Interaction Amino Acid Consensus (CRAC) of the 
Peripheral-Type Benzodiazepine Receptor and Inhibition of Steroidogenesis by an HIV TAT-CRAC Peptide, Proc. Natl. Acad. Sci. USA, vol. 98, pp. 1267-1272.

Li, M.O., Sarkisian, M.R., Mehal, W.Z., Rakic, P. \& Flavell R.A. (2003). Phosphatidylserine Receptor Is Required for Clearance of Apoptotic Cells, Science, vol. 302, pp. 15601563.

Lin, D., Lobell, S., Jewell, A. \& Takemoto, D.J. (2004). Differential Phosphorylation of Connexin 46 and Connexin 50 by $\mathrm{H}_{2} \mathrm{O}_{2}$ Activation of Protein Kinase $\mathrm{C} \gamma$, Mol. Vis., vol. 10, pp. 688-695.

Lin, D., Zhou, J., Zelenka, P.S. \& Takemoto, D.J. (2003). Protein Kinase C $\gamma$ Regulation of Gap Junction Activity through Caveolin-1-containing Lipid Rafts, Invest. Ophthalmol. Vis. Sci., vol. 44 (12), pp. 5259-5268.

Lin, E.Y," Li, J.F., Gnatovskiy, L., Deng, Y., Zhu, L., Grzesik, D.A., Qian, H., Xue, X.N. \& Pollard, J.W. (2006). Macrophages Regulate the Angiogenic Switch in a Mouse Model of Breast Cancer, Cancer Res., vol. 66 (23), pp. 11238-11246.

Lingwood, D. \& Simons, K. (2010). Lipid Rafts As a Membrane-Organizing Principle, Science, vol. 327, pp. 46-50.

Lucas, A.D. \& Greaves, D.R. (2001). Atherosclerosis: Role of Chemokines and Macrophages, Expert. Rev. Mol. Med., vol. 3 (25), pp. 1-18.

Marois, L., Paré, G., Vaillancourt, M., Rollet-Labelle, E. \& Naccache, P.H. (2011) FcyRIIIb Triggers Raft-dependent Calcium Influx in IgG-mediated Responses in Human Neutrophils, J. Biol. Chem., vol. 286 (5), pp. 3509-3519.

May, R.C. \& Machesky, L.M. (2001). Phagocytosis and the Actin Cytoskeleton, J. Cell Sci., vol. 114, pp. 1061--1077.

Morrissette, N.S., Gold, E.S., Guo, J., Hamermann, J.A., Ozinsky, A., Bedian, V. \& Aderem, A.A. (1999). Isolation and Characterization of Monoclonal Antibodies Directed against Novel Components of Macrophage Phagosomes, J. Cell Science, vol. 119, pp. 4705-4713.

Mosser, D.M. (1994). Receptors on Phagocytic Cells Involved in Microbial Recognition, Immunol. Ser., vol. 60, pp. 99-114.

North, R.A. (2002). Molecular Physiology of P2X Receptors, Physiol. Rev., vol. 82 (4), pp. 1013-1067.

Ofek, I., Goldhar, J. \& Sharon, N. (1995). Nonopsonic Phagocytosis of Microorganisms, Ann. Rev. Microbiol., vol. 49, pp. 239-276.

Pelkmans, L., Puentener, D. \& Helenius, A. (2002). Local Actin Polymerization and Dynamin Recruitment in SV40-induced internalization of Caveolae, Science, vol. 296, pp. 535539.

Peyron, P., Bordier, C., N'Diaye, E.-N. \& Maridonneau-Parini, I. (2000). Nonopsonic Phagocytosis of Mycobacterium kansasii by Human Neutrophils Depends on Cholesterol and Is Mediated by CR3 Associated with Glycosylphosphatidylinositol-Anchored Proteins, J. Immunol., vol. 165, pp. 51865191.

Pike, L.J. (2003). Lipid Rafts: Bringing Order to Chaos, Journal of Lipid Research, vol. 44 (4), pp. 655-667. 
Pradhan, D., Krahling, S., Williamson, P. \& Schlegel, R.A. (1997). Multiple Systems for Recognition of Apoptotic Lymphocytes by Macrophages, Mol.Biol. Cell, vol.8, pp. 767-778.

Pratten, M.K. \& Lloyd, J.B. (1986). Pinocytosis and Phagocytosis: The Effect of Size of a Particulate Substrate on Its Mode of Capture by Rat Peritoneal Macrophages Cultured In Vitro, Biochim. et biophys. Acta, vol. 881, pp. 307-313.

Rabinovitch, M. (1995). Professional and Nonprofessional Phagocytes: An Introduction, Trends Cell Biol., vol. 5, pp. 85-87.

Ross, G.D. \& Větvicka, V. (1993). CR3 (CD11b, CD18): A Phagocyte and NK Cell Membrane Receptor with Multiple Ligand Specificities and Functions, Clin. Exp. Immunol., vol. 92 (2), pp.181-184.

Saxena, R.K., Gilmour, M.I. \& Hays, M.D. (2008). Isolation and Quantitative Estimation of Diesel Exhaust and Carbon Black Particles Ingested by Lung Epithelial Cells and Alveolar Macrophages In Vitro, Biotechniques, vol. 44 (6), pp. 799-805.

Schreiber, A.D., Parsons, J., Mcdermot, P. \& Cooper R.A. (1975) Effect of Corticosteroids on the Human Monocyte IgG and Complement Receptors, J. Clin. Invest. Vol. 56, pp. 1189-1197.

Schubert, A.L, Schubert, W., Spray, D.C. \& Lisanti, M.P. (2002). Connexin Family Members Target to Lipid Raft Domains and Interact with Caveolin-1, Biochemistry, vol. 41 (18), pp. 5754--5764.

Simons, K. \& Ikonen, E. (1997). Functional Rafts in Cell Membranes, Nature, vol. 387, pp. 569-572.

Takahashi, K., Takeya, M. \& Sakashita, N. (2002). Multifunctional Roles of Macrophages in the Development and Progression of Atherosclerosis in Humans and Experimental Animals, Med. Electron Microsc., vol. 35 (4), pp. 179-203.

Tidball, J.G. \& Wehling-Henricks, M. (2007). Macrophages Promote Muscle Membrane Repair and Muscle Fibre Growth and Regeneration during Modified Muscle Loading in Mice In Vivo, J. Physiol., vol. 578 (Pt 1), pp. 327-336.

Tjelle, T.E., Levdal, T. \& Berg, T. (2000). Phagosome Dynamics and Function, BioEssays, vol. 22 , pp. $255-263$.

Torres, G.E., Egan, T.M. \& Voigt, M.M. (1999). Hetero-oligomeric Assembly of P2X Receptor Subunits, J. Biol. Chem., vol. 274, pp. 6653-6659.

Turner, R.A., Schumacher H. R. \& Myers A.R. (1973). Phagocytic Function of Polymorphonuclear Leukocytes in Rheumatic Diseases, J. Clin. Invest., vol. 52 (7), 1632-1635.

Vandivier, R.W., Fadok, V.A., Hoffman, P.R., Bratton, D.L., Penvari, C., Brown, K.K., Brain, J.D., Accurso, F.J. \& Henson P.M. (2002). Elastase-Mediated Phosphatidylserine Receptor Cleavage Impairs Apoptotic Cell Clearance in Cystic Fibrosis and Bronchiectasis, J. Clin. Invest., vol. 109, pp. 661-670.

Vishniakova Kh. S., Kireev I. I. \& Dunina-Barkovskaya A.Ya. (2011). Effects of Cell Culture Density on Phagocytosis Parameters in IC-21 Macrophages, Biochemistry (Moscow) Supplement Series A: Membrane and Cell Biology, vol. 5 (4), pp. 355-363 [Original Russian Text in: Biologicheskie membrany (Rus.), vol. 28 (5), pp. 387-396]. 
Werb, Z. \& Cohn, Z.A. (1972). Plasma Membrane Synthesis in the Macrophage Following Phagocytosis of Polystyrene Latex Particles, J. Biol. Chem., vol. 247, pp. 2439-2446.

Yeung, T., Heit, B., Dubuisson, J.-F., Fairn, G.D., Chiu, B., Inman R., Kapus, A., Swanson, M., \& Grinstein, S. (2006). Contribution of Phosphatidylserine to Membrane Surface Charge and Protein Targeting during Phagosome Maturation, J. Cell Biol., vol. 185 (5), pp. 917-928.

Young J.D., Unkeless J.C., Cohn Z.A. (1985). Functional Ion Channel Formation by Mouse Macrophage IgG Fc Receptor Triggered by Specific Ligands. J. Cell Biochem., vol. 29, pp. 289-297.

Young J.D., Unkeless J.C., Young T.M., Mauro A., Cohn Z.A. (1983). Role for Mouse Macrophage IgG Fc Receptor as Ligand-Dependent Ion Channel, Nature, vol. 306 (5939), pp. 186-189. 


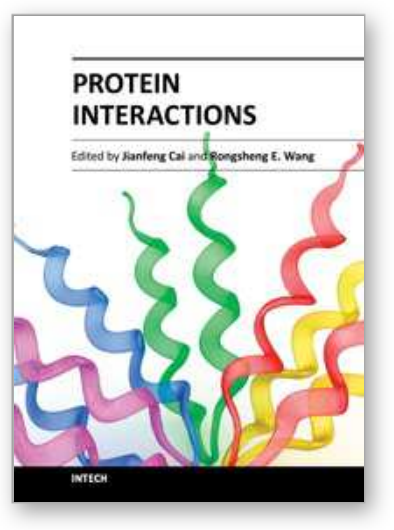

\author{
Protein Interactions \\ Edited by Dr. Jianfeng Cai
}

ISBN 978-953-51-0244-1

Hard cover, 464 pages

Publisher InTech

Published online 16, March, 2012

Published in print edition March, 2012

Protein interactions, which include interactions between proteins and other biomolecules, are essential to all aspects of biological processes, such as cell growth, differentiation, and apoptosis. Therefore, investigation and modulation of protein interactions are of significance as it not only reveals the mechanism governing cellular activity, but also leads to potential agents for the treatment of various diseases. The objective of this book is to highlight some of the latest approaches in the study of protein interactions, including modulation of protein interactions, development of analytical techniques, etc. Collectively they demonstrate the importance and the possibility for the further investigation and modulation of protein interactions as technology is evolving.

\title{
How to reference
}

In order to correctly reference this scholarly work, feel free to copy and paste the following:

Antonina Dunina-Barkovskaya (2012). Cholesterol-Binding Peptides and Phagocytosis, Protein Interactions, Dr. Jianfeng Cai (Ed.), ISBN: 978-953-51-0244-1, InTech, Available from:

http://www.intechopen.com/books/protein-interactions/cholesterol-binding-peptides-and-phagocytosis

\section{INTECH}

open science | open minds

\section{InTech Europe}

University Campus STeP Ri

Slavka Krautzeka 83/A

51000 Rijeka, Croatia

Phone: +385 (51) 770447

Fax: +385 (51) 686166

www.intechopen.com

\section{InTech China}

Unit 405, Office Block, Hotel Equatorial Shanghai

No.65, Yan An Road (West), Shanghai, 200040, China

中国上海市延安西路65号上海国际贵都大饭店办公楼 405 单元

Phone: +86-21-62489820

Fax: +86-21-62489821 
(C) 2012 The Author(s). Licensee IntechOpen. This is an open access article distributed under the terms of the Creative Commons Attribution 3.0 License, which permits unrestricted use, distribution, and reproduction in any medium, provided the original work is properly cited. 